\title{
焼入炭素鋼の機械的性質および焼入性におよぼす オーステナイト化条件の影響*
}

飯 島 一 昭**

Kazuaki Iijima: The Effect of Austenitizing Condition on Hardenability and on Mechanical Properties of Hardened Carbon Steel. The effects of austenitizing conditions, such as austenitizing temperature, austenitizing time and the austenitizing temperature in previous heat treatment, on the hardenability and the mechanical properties of hardened eutectoid carbon steel were determined, and the relations between those properties and the austenitic grain size were ascertained, with the following results: (i) The higher the austenitizing temperature, the lower the toughness of hardened steel, the greater its hardenability, and the coarser its austenitic grain size; (ii) a longer austenitizing time gives the same effect as higher austenitizing temperature on those properties, but in some cases, an abrupt change in toughness and hardenability unrelated with austenitic grain size was observed; (iii) even if the austenitizing temperature in final hardening was maintained constant $\left(800^{\circ} \mathrm{C}\right)$, the toughness and the hardenability were remarkably affected by the austenitizing temperature in previous heat treatment, such as annealing, hardening and annealing after hardening, where the higher was the austenitizing temperature, the toughness fell the lower and the hardenability rose the higher. But, in all cases, the austenitic grain size was scarcely affected by previous heat treatment; (iv) the above results suggest that decrease in toughness and increase in hardenability due to overheating would be attributed to some change in austenite produced by the overheating process itself, in addition to austenitic grain coarsening.

(Received July 3,1961 )

\section{I. 緒言}

焼入加熱の際，オーステナイト化温度を上杽せしめるに

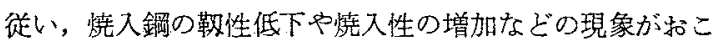
ること虫古くからよく知られているが，これらの原因はい ずれる，加熱温度の上界比ともなう。オーステナイト結晶 粒の粗大化炕よるのと考完られている(1)ー(7).

しかて，焼入鋼の靱性に関しては、オーステナイト結晶 粒度(以下単汇粒度と称する)そのものが，それを支配する とい弓考光に惊，末た疑閣の点が残されているようであ

** 鉄道技術研究所 (The Railway Technical Research Institute, Tokyo)

* 機珹的性質に関して：1957年 10 月本会戸畑大会に 発表；焼入性㳊関して：1958年 10 月本会名古屋大 会汇発表

(1) E.S.Davenport, E.L.Roff, E.C.Bain: Trans. ASM, 22 (1934), 289

(2) E.S. Davenport, E. C. Bain: Trans. ASM, 22 (1934), 879 .

(3) P.Schane: Trans. ASM , 22 (1934), 1038.

(4) C.H.Herty, D. L. McBride, E.H.Hollenback: Trans. ASM, 25 (1937), 297.

(5) R.F.Meh1: Trans. ASM, 29 (1941), 813.

（6）佐藤，真野，戸谷，苫来地：本誌，19(1955)，177.

(7) H.Borchers, G. Saur: Stahl u. Eisen, 78(1958), 40:

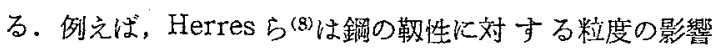
は間接的でめり，粒境界への析出物などの存在が大きい影 響をもつといって括り，またBullens(9) はとの著書に拈い て，鋼の勒性を支配するすのは粒度そのすのではなく，粒 成長に並行して生ずる各種成分元素の固溶あるいは析出な ぞによると信ずべき理由があると述へてている。

著者は，焼入直前のオーステナイト結晶粒度と焼入鍓の 機械的性質および焼入性との間にどのような関連性がある かを確かめるため, 共析付近の炭素鋼について,オースラ ナイト化温度, 時間㧍よび前熱処理などを種々变化せしめ た場合の両者の関係を検討したので方る。

\section{II. 実 験 方 法}

1. 試 料

Table 1 は本突験に用いた試料の化学組成を示するの である。

$0.80 \% \mathrm{C}$ 鋼は拱り試験に，また $0.85 \% \mathrm{C}$ 鋼は焼入性試 験にそれぞれ使用したものである．Fig.1は試験片の形状

(8) S.A.Herres,C.H.Lorig: Trans.A.SM, 40 (1948), 775.

(9) D.K.Bullens: Steel and Its Heattreatment, Vol. 1,5 th Ed, (1948), 373,386. 
寸法を図示したもので，㨝り試験片 (a)，焼入性試験片 (b) をそれぞれ示するのである。

Table 1 Chemical composition of specimens (wt \%).

\begin{tabular}{c|c|c|c|c}
\hline \hline $\mathrm{C}$ & $\mathrm{Si}$ & $\mathrm{Mn}$ & $\mathrm{P}$ & $\mathrm{S}$ \\
\hline 0.80 & 0.22 & 0.38 & 0.029 & 0.009 \\
0.85 & 0.30 & 0.40 & 0.018 & 0.018 \\
\hline
\end{tabular}

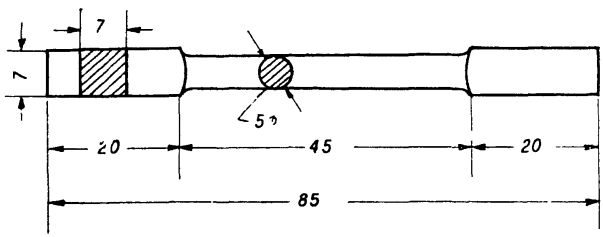

(a) Torsion test piece

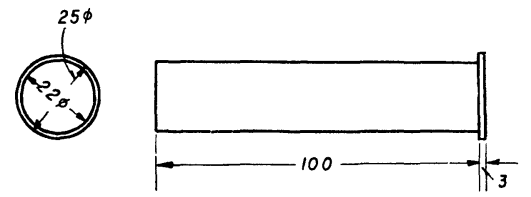

(b) Hordenability lest piece

Fig.1 Dimensions of test piece.

\section{2. 実験方法}

(1) 熱処理

(i) オーステナイト化温度

㨝り圾鈳片については $750 \sim 1100^{\circ} \mathrm{C}$ の，をた焼入性試験 片については $750 \sim 1000^{\circ} \mathrm{C}$ の各温度にいずれも $1 \mathrm{hr}$ 保持 (真空炉中) 後, その温度から焼入を行なつた。

\section{(ii) オーステナイト化時間}

㨝り試験片については $750^{\circ}, 800^{\circ}$ および $900^{\circ} \mathrm{C} に$ にまた 焼入性試検片については $900^{\circ} \mathrm{C}$ に，それぞれオーステナイ ト化温度を一定し，保持時間を $10 \mathrm{~min} \sim 10 \mathrm{hr}$ の範团内で 変化せしめた。

\section{(iii) 前熱処理}

最終焼入時のオーステナイト化温度を $800^{\circ} \mathrm{C}$, 保持時間 を $1 \mathrm{hr}$ に一定し, 前熱処理時のオーステナイト化温度を $750 \sim 1100^{\circ} \mathrm{C}$ の範团内で変化せしめた.

㨝り試験片に対する前熱処理としては

(i) 焼なまし $\left(750 \sim 1100^{\circ} \mathrm{C}\right)$

(ii) 焼入 $\left(750 \sim 1100^{\circ} \mathrm{C}\right)$

(iii) 焼入 $\quad\left(750 \sim 1100^{\circ} \mathrm{C}\right)$ の後, 煌なまし $\left(800^{\circ} \mathrm{C}\right)$

の 3 種を採用し，保持時間をいずれも $1 \mathrm{hr}$ に一定せしめ た。

また，焼入性試験片に対する 前熱処理としては750～ $1000^{\circ} \mathrm{C}$ の焼なまし $(1 \mathrm{hr})$ を採用した。

\section{(2) 据り試験}

試験はいずれも焼入(種油中焼入)ままのものについて行 なつた. 試験機はアムスラ一式㨝り試験機(容量 $30 \mathrm{~kg}-$ $\mathrm{cm})$ を使用し，㨝り強さ $\left(\tau_{B}\right)$ および塑性㨝り角 $\left(\theta_{P}\right)$ (Fig.2 参照)を測定した。
なお，試験片のつかみ部について焼入硬さの測定を行な つた.

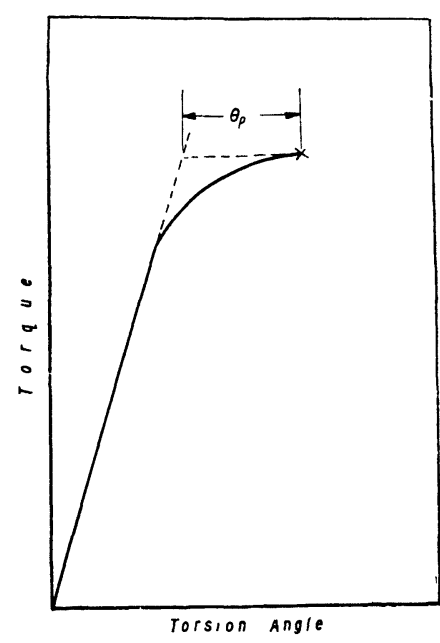

Fig.2 Torque-torsion angle diagram. $\theta_{p}$ : plastic torsion angle.

\section{(3) 焼入性試験}

一端水冷のジョミニ 一試験を行い, 試験片 の側面について軸方向 に Rc 硬さ試験抽よび 顕微鏡組織検査を行な つた.この結果から，

焼入硬さ：水冷端の 硬さ, Rc

$D_{\mathrm{M}}:$ マルテンサイ 卜組織の相厚, $\mathrm{mm}$

$D_{\mathrm{M}}+T:$ マテルン サイト+トルー スタイト組織の 相厚, $\mathrm{mm}$

$J_{40}$ : 水冷端か 5 Rc 40を示す部位ま
での距離, $\mathrm{mm}$

焼ならし硬さ：空冷端の硬さ, Rc をそれぞれ測定し，焼入性を示す尺度とした。

(4) 結晶粒度の測定

(i) 㨝り試験片

焼入後 $250^{\circ} \mathrm{C}$ に $30 \mathrm{~min}$ 間加熱したものについて Viella および Bain 試薬(10)腐食を行ない顕出した。

\section{(ii) 焼入性試験片}

試験後マルテンサイト+トルースタイト組織の部位につ いて測定した.

\section{III. 実 験 結 果}

\section{1. 㨝り試 験}

Fig.3 はオーステナイト化温度を調えたときの諸性質変 化を図示したものである．結晶粒は温度とともに次第に粗 大化するが，㨝り強さ括よび塑性据り角は約 $850^{\circ} \mathrm{C}$ に極大 值を示した後急激に低下する. $950^{\circ} \mathrm{C}$ を超すと塑性はほと んど認められなくなり，脆化が行なわれたことを示してい る.

Fig.4はオーステナイト化温度を一定とし，保持時間を 変えた場合の諸性質の変化を示したものである，粒度には 時間による変化はほとんど認められないが，㨝り強さ括よ び塑性㨝り角にはそれが明らかに認められる。とくに, $900^{\circ} \mathrm{C}$ 保持の場合約 $1 \mathrm{hr}$ 保持後にいずれす極大を示した 後, 急激に脆化する傾向が示されている.

Fig.5は前熱処理時のオーステナイト化温度を変えた場 合の最終焼入 $\left(800^{\circ} \mathrm{C}, 1 \mathrm{hr}\right)$ 後の諸性質の変化を示すもの である。粒度はほぼ一定值を示すが，強さおよび望性には 前熱処理に括けるオーステナイト化温度の影響が顕著に認

(10) E.C.Bain, J.R.Vilella: ASM Metals, Handbook (1948) ,399. 
められ，一度過熱による脆化を乱こしたものは，少くとも この程度の後処理によつては恢復されないことを示してい る.

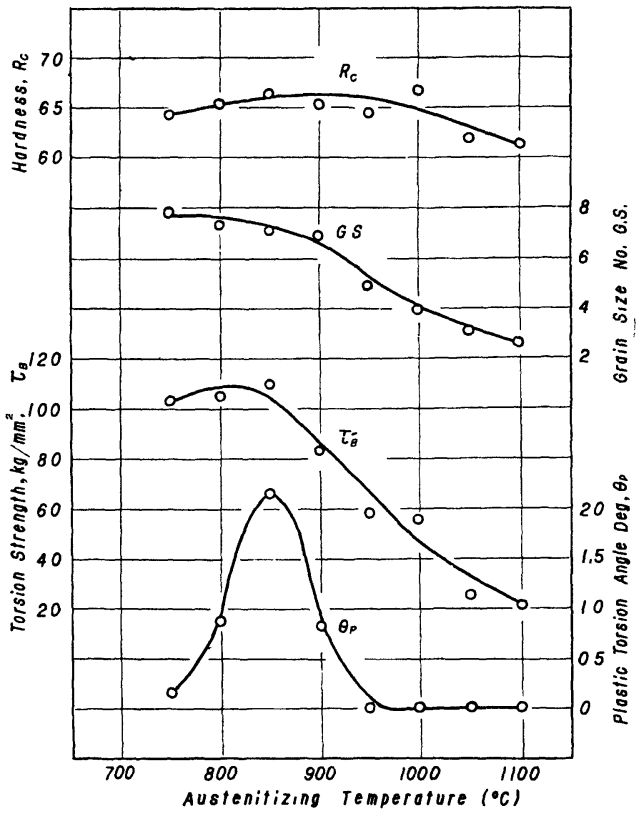

Fig.3 The effect of austenitizing temperature on mechanical properties of hardened $0.80 \% \mathrm{C}$ steel.

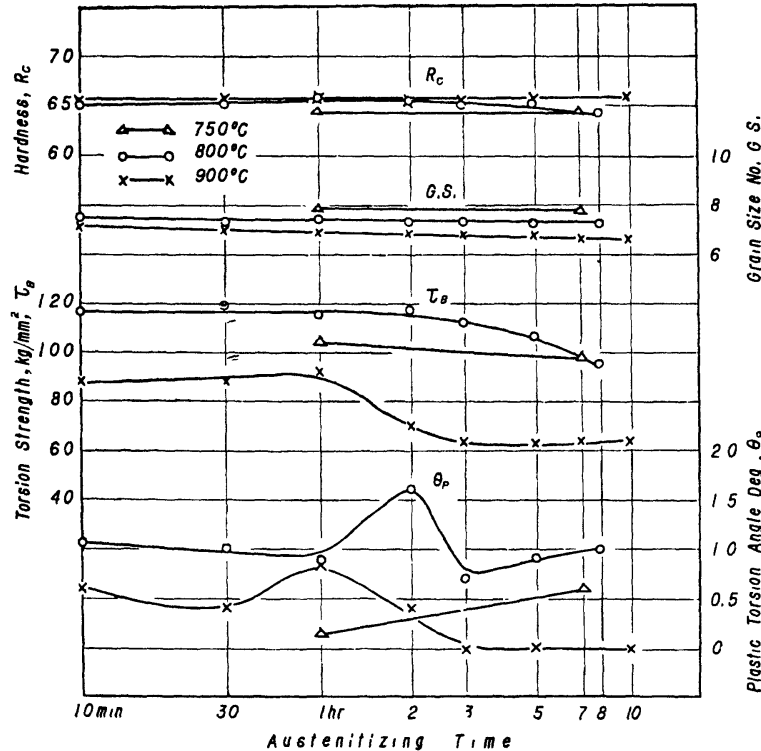

Fig.4 The effect of austenitizing time on the mechanical properties of hardened 0.80 $\%$ C steel.

\section{2. 焼入性試験}

Fig.6は粒度および焼入性におよぼすオーステナイト化 温度の影響を示するので, 温度上年にともなう粒の粗大化 および焼入性の向上が明らか哂認めらる。な敃，図中， オーステナイト化温度の上型にとるなら焼ならし硬さの增 加が認められるが，これは $\mathrm{Ar}_{1}$ 変態点がオーステナイト化
温度の上型に従つて降下し，そのために，生成されるパー ライト組織（パーライトの間隔，地鉄の厚さ，セメンタイ トの厚さ）が微細化することによるるのと考光れる．この

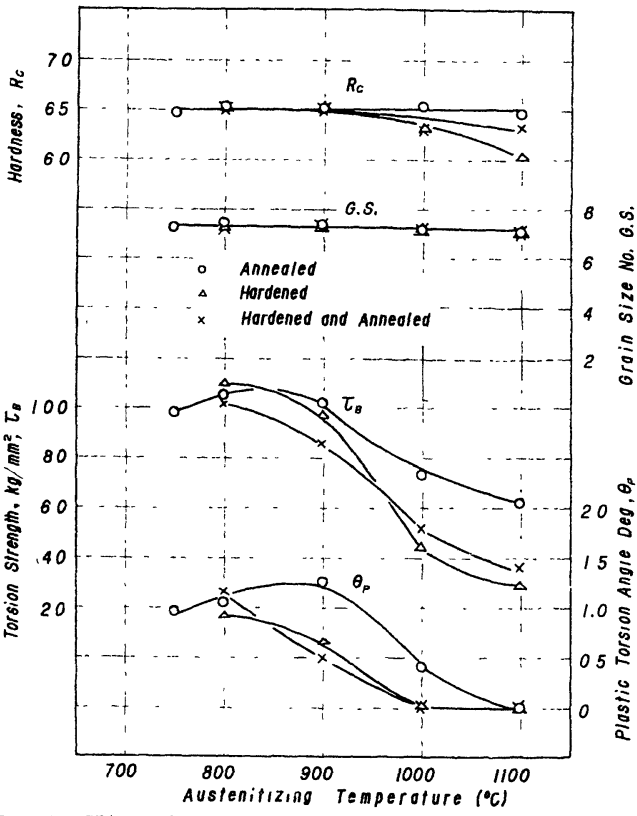

Fig.5 The effect of austenitizing temperature in previous heat treatment on the mechanical properties of $0.80 \% \mathrm{C}$ steel, austenitizing temperature in final quenching is $800^{\circ} \mathrm{C}$.

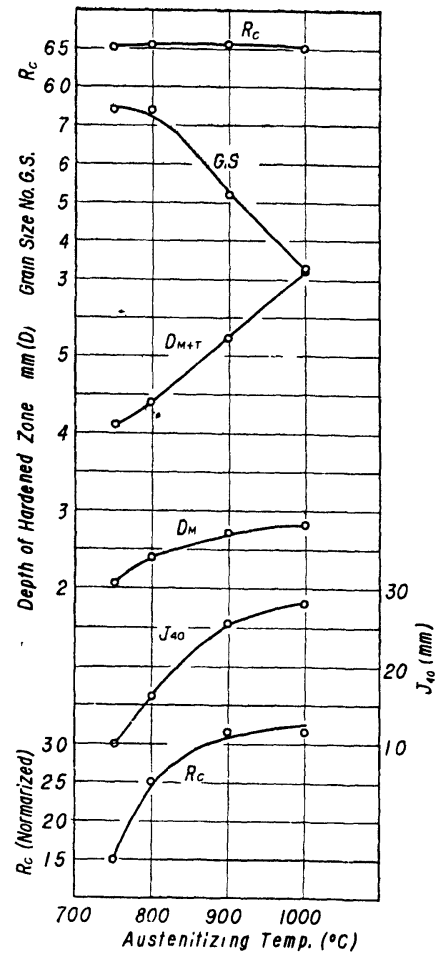

Fig.6 The effect of austenitizing temperature on hardenability of $0.85 \% \mathrm{C}$ steel.

$D_{\mathrm{M}}$ : Depth of Martensite zone.

$D_{\mathrm{M}+\mathrm{T}}$ : Depth of Martensite+ Troostite zone.

$J_{40}$ : Distance from quenched end to the position showing Rc 40 . 
現象はオーステナイト化温度の上昇が，冷却時にパーライ トの生成を遅らせるという点で, 焼入性の向上を間接的に 実証するものといらことができる。

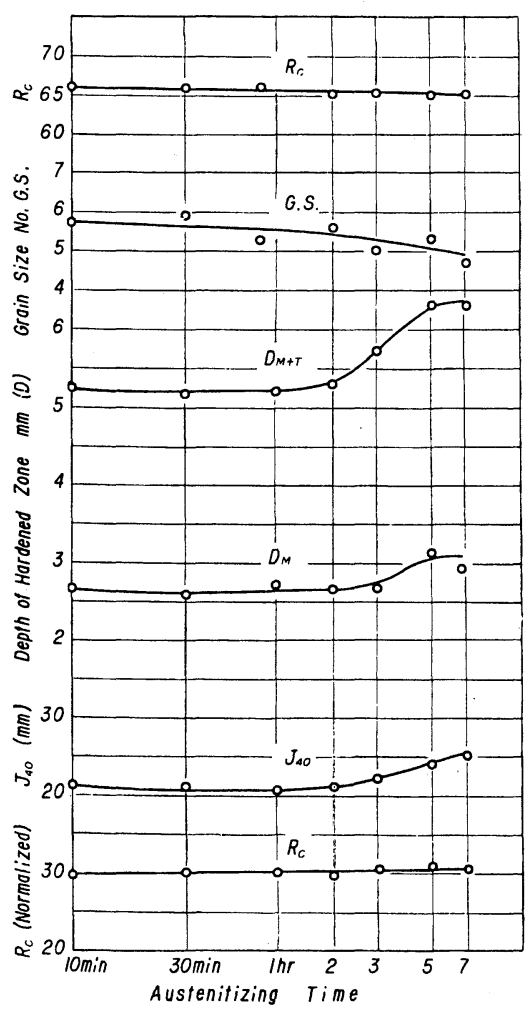

Fig.7 The effect of austenitizing time on hardenability of $0.85 \% \mathrm{C}$ steel, austenitizing temperature is $900^{\circ} \mathrm{C}$.

Fig.7は粒 度扣よび焼入 性に拉よぼす オーステナイ ト化時間の影 響を示すもの で，温度は $900^{\circ} \mathrm{C}$ 一定で ある。図から 明らかなよう に, 約 $1 \mathrm{hr}$ 保 持後に粒度の 変化とは無関 係な焼入性の 急激な增加が 認められる が,これは Fig.4の㨝り である。 強さ牤よび塑 性の変化の場 合と現象的に 一致するもの

Fig.8は最 終焼入時の才 ーステナイト化温度を $800^{\circ} \mathrm{C}, 1 \mathrm{hr}$ 保持に一定し, 前熱処 理 (焼鈍) 温度を $750^{\circ} \sim 1000^{\circ} \mathrm{C} に$ 変えた場合の粒度执よび 焼入性の変化を図示したものである，粒度はほぼ一定值を 示すが，焼入性には前処理の影響が顕著に認められる.こ の現象もFig.5㹉り強さおよび望性の変化の場合と現象的 によく一致する.

\section{IV. 考察}

Fig.3 扎よびFig.6 のように, 普通にオーステナイト化 を行なつた場合は, 温度上昇にともなう, 粒の粗大化, 䩲 性の低下括よび焼入性の增加が認められ，これだけから判 断すれば，粒の粗大化のみが靱性や焼入性を支配している ように考觉られる.しかしながら，Fig.5 执よびFig.8のよ ろに前熱処理として過熱操作（燃焼組織を呈するには至ら ないが変態点以上相当に高い温度に加熱する）を加えるこ とによつて，たとえ最終焼入時のオーステナイト化温度を 一定にし，粒度を同一にしても，靱性や焼入性がその前熱 処理によつて大きく変化すること，また，Fig.4および Fig.7のよ5に，オーステナイト化時間を変えることによ つて，それらの諸性質が粒度とはほぼ無関係に変化するこ となどの現象は，靱性および焼入性を支配する因子が粒度
だけではなく，それ以外にも存在することを示すものと考 えられる。

オーステナイトの温度上异や保持時間の增加が, まず,

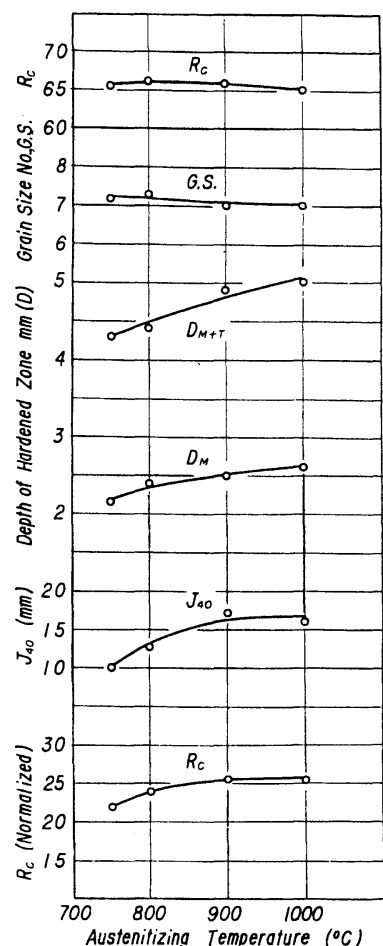
ing temperature in previous annealing on hardenability of $0.85 \% \mathrm{C}$ steel, austenitizing temperature in final quenching is $800^{\circ} \mathrm{C}$
Fig.8 The effect of austenitiz
セメンタイトあるいは 炭化物の固溶によるオ ーステナイトの炭素濃 度增加拉よび均質化を もたらし，このために 靱性低下や焼入性の増 加がおこることはよく 知られている(11)〜(14).

しかしながら, Meh1 (15)によれば,0.85\% C 鋼におけるセメンタイ トの固溶終了执よびオ ーステナイトの炭素濃 度均質化の終了に要す る大よその時間は 800 'C に扣いて 1 min $840^{\circ} \mathrm{C}$ では $18 \mathrm{sec}$ 扣よ び 4 min である，従つ て，本実験におけるよ 弓な $900^{\circ} \mathrm{C}, 1 \mathrm{hr}$ 以上 の加熱(過熱)による靶 性低下や焼入性增加は オーステナイト中への セメンタイト固溶によ

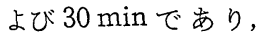
る炭素濃度増加やその均質化に基因するものではなく，他 の原因によるものと考えなければならない。

過熱による勒性低下が，粒界への不純物などの析出によ るとする説(8)(9)があることについては緒言でも述べたが， この他にも, このような現象, すなわち, 過熱に基づく粒 界へのプラスまたはマイナスの吸着作用(16)(17) による組成 の不均質化や不純物析出量の濃化が靱性低下を招来するこ とが認められている(18)〜(21).

(11) 山田，横山：本誌, 14(1950), 42 .

(12) 大和久, 飯島：本誌, 18(1954),362.

(13) 田中：本誌, 19 (1955), 509 .

(14) 原, 三浦, 杉山：本誌, $20(1956), 1$

(15) R.F.Meh1: Trans. ASM, 29 (1941) , 813.

(16) J.W.Sprenak, R.Speiser: Trans.ASM, 43 (1951), 734 .

(17) L.Colombier: Metal Progress, 67 (1955) , 116.

(18) A.Preece, A.Hartley, S.E.Mayer, J.Nutting: J. Iron Steel Inst., 153 (1946) ,237.

(19) A.Preece, J.Nutting, A.Hartley : J.Iron Steel Inst., $164(1950), 37$.

(20) A. Preece, J. Nutting : J.Iron Steel Inst., 164 (1950), 46.

(21) T.Ko, D.Hanson: J.Iron Steel Inst.,164 (1950), 51.

(22) 今井：本誌, $19(1955), 106$. 
焼入性济響をおよぼす粒度以外の因子が何であるかは まだ明らかで忧いが，鋼への㻚素添加の効果が，粒界へ の吸着澧化によるパーライト核の発生阻止作用に上て説明 (22)されている例加む，この上5なオーステナイト中に扔 ける变化が勒性のみならす焼入性炕する程度の影響を与 えることが考えられる。

\section{V. 結}

\section{言}

オーステナイト化温度, 同時間特よび前熱処理時のオ一 ステナイト化温度が燒入れした共析鋼の据り強さ，塑性㨝 り角扣よび狫入性などに打よぼす影響をオーステナイト結 晶粮度との関連に抢いて検款した，その結果はつぎの通り である。

（1）オーステナイト化温度の上年にとむない，焼入鋼の 靱性低下，焼入性の增加就よび結晶粒の粗大化が認められ た。

（2）オーステナイト化時間を增加させることは，オース
テナイト化温度を上界させるのとほぼ同様の影響を与える が，結晶粒成長とは無関係な靶性叔よび嫃入性の顕著な変 化が認められた。

(3) 最終焼入時のオーステナイト化温度を一定とし，前 熱処理時のオーステナイト化温度を変化させた場合, 結晶 粒度がはぼ一定值を示すのに反し，靶性和よび暁入性には 前熱処理時のオーステナイト化温度の影響が明らかに認め られた。

（4）以上の諸結果は，過熱俘よる勒性低下や焼入性增加 が結晶粒の粗大化のみならず，過熱なる操作そのるのに㷌 因する他の未知の変化沈る原因することを示すものと考え られる，過熱がどのような变化をオーステナイトに与劣る がついてはまだ明らかでないが，粒界吸着作用によるオ ーステナイトの組成不均質化や不純物析出量の濃化などが 考党られる。

終りに，本実験を行なうにあたり衡指導をいただいた当 所金属材料研究室長大和久重雄博士に深く感謝する。 